\title{
THE CONTRIBUTION OF ROSE AND ROSEWATER TOURISM AND FESTIVAL TO THE DESTINATION IMAGE
}

Hamira Zamani- Farahani

Astiaj Tourism Research and Consultancy Centre \& Department of Tourism and Hospitality West Tehran Branch - Islamic Azad University, Tehran-Iran Dorothy Fox

Faculty of Management Bournemouth University

Dorset House, Talbot Campus - Fern Barrow, POOLE, Dorset UK

\section{AUTHOR NOTES}

Corresponding Author: Hamira Żamani-Farahani, PhD, Astiaj Tourism Research and Consultancy Centre \& Department of Tourism and Hospitality West Tehran Branch - Islamic Azad University, P.O. Box_16335-199, Tehran-Iran. Email: hzfara@gmail.com

Dorothy Fox, PhD. Faculty of Management Bournemouth University, Dorset House, Talbot Campus, Fern Barrow, POOLE, Dorset, BH12 5BB, Tel: +44 (0)1202 961578, (D115). Email: DFox@bournemouth.ac.uk

\section{ACKNOWLEDGEMENT}

This work was partially supported by the West Tehran Branch, Islamic Azad University, TehranIran, under Grant number 08-15-1/5969. 


\begin{abstract}
This study seeks to explore rose and rosewater tourism and festival to understand how tourist attitudes to the festivals contribute to their image of the destination. To achieve this survey of domestic tourists was undertaken in the Kashan region of Iran. The results provide some original insights into the selection of destinations which are of value to academics, industry practitioners, tourism planners and policymakers. It confirms that events and festivals cannot develop or grow without the support of the hospitality and tourism industries. Some of the cultural limitations of undertaking the research, together with suggestions for future research are also discussed.
\end{abstract}

Keywords: Damask rose and rose water tourism, Rose and rosewater festival; Tourist attitudes; Destination image; Tourist preferences; Iran (Kashan))

\title{
INTRODUCTION
}

A tourism destination comprises of a number of elements namely: attractions, amenities, accessibility, image, price and human resources (United Nations World Tourism Organisation (UNWTO), 2007). The provision and quality of these elements will be influential in the visitors' decision making process, particularly their choice of destination, as the particular mixture of products offered delivers an integrated experience to consumers (Buhalis, 2000). The growing number of new tourism destinations and the changing attitudes of visitors are forcing tourism destinations to enhance their products, management and marketing strategies. Festivals and special events are one type of cultural resource which can bring income to a local community (Backman, Backman, Uysal, \& Sunshine, 1995). Therefore, special events are regarded as a potentially important generator of economic activity and job opportunities (Dwyer, Forsyth, \& 
Spurr, 2005), as well as a means of promoting and improving the image of a destination (Candrea \& Ispas, 2010).

Events and festivals are widely recognized as a means of developing tourism and enhancing economic impacts for a destination (Devine \& Devine, 2017; Getz, 2013). For the tourism industry in a country such as Iran, which has suffered from a range of issues including political instability; regional conflict and 'negative imagery' (Khodadadi, 2016 p. 6) addressing this problem is paramount if both the events and tourism industries are to develop. Continued recognition that the image of an event is intrinsically linked to the image of the destination is vital for all nations, but crucially for countries like area of present research that are emerging from conflict or other crises. Whilst there is a need to improve infrastructure there, the development of appropriate tourism products, such as events and festivals is also required. Identifying the importance and contribution of both elements is therefore necessary, to enhance the event attendees' image of the destination and hence their likelihood to attend events there.

The satisfaction of the visitors and the attitudes of tourists in relation to their preferences and the destination image have been the subject of considerable research over the past three decades. However, with the increasing use of festivals and events to attract tourists to an area, the utilisation of this approach in respect of event tourism makes it worthy of further attention. The balance of importance to consumers, between the event product and the tourism product, needs to be understood by communities, in order to best invest in marketing and infrastructure etc.

Iran has had a long, complex and at times, difficult history and its political orientation may have limited the growth of tourism (Zamani-Farahani \& Musa, 2012). The country has also faced 'inefficient and inequitable tourism development planning and management, deficiencies 
in the stock of accommodation, lack of well-developed transport infrastructure and a rigid social code" (Zamani-Farahani, 2013, p.252). Furthermore, Morakabati (2011) states that tourism in Iran was then not yet a priority despite many officials suggesting that it is essential to economic development.

A previous study in Iran (Ghaderi, 2011) demonstrated that leisure activities form domestic tourists' most important focus and in common with many other countries events and festivals are important attractions. In an era of increasing global urbanisation, a community's connection with its traditional agricultural produce is limited and therefore festivals and events, celebrating local, culturally significant products, are increasing.

Previous studies from other countries have considered wine, tea, and coffee tourism amongst others, but to date it appears that there have been no studies of rosewater tourism. This study begins therefore by describing rose and rosewater tourism around the world. This provides the context to then examine the relationship between a rosewater festival the regional tourism industry which hosts it. The Kashan region in Iran is one of the largest rose and rose water production destination in the world (Chwalkowski, 2016) and therefore forms the context of this study. Knowledge of the contribution of the rosewater festivals in the tourism development offer will therefore be of yalue, as there is the potential to expand both domestic and international visitors including those of Muslim and non-Muslim faith (Jafari \& Scott, 2014).

Rose and rosewater tourism is an emerging form of alternative tourism that can be variously categorised as agricultural, rural, recreational or special interest tourism. According to Read (1980, p.195), special interest tourism is defined "as travel for people who are going somewhere, because they have a particular interest that can be pursued in a particular region or at 
a particular destination." It is the motivation around which the total travel experience is planned and developed. For other festival attendees, the event may be of secondary importance in selecting a destination. It is the potential of both kinds of travel experience that needs to be addressed to a greater extent, therefore justifying this research. We define rosewater tourism as visitation to rose growing farms, rosewater distilleries, enjoying rose-based food and beverages, and rosewater festivals and exhibitions. Rose and rosewater tourism takes place in just a few countries around the world and to date there has been very limited study of it (a brief reference in Fox, Gouthro, Morakabati, \& Brackstone, 2014 is a rare exception). Thepresent study is therefore pioneering in exploring the features of rose and rosewater tourism and providing insights into tourist attitudes towards this form of tourism.

The aim of the paper therefore is to explore rose and rosewater tourism/ events and to identify the perceptions of tourists with a particular interest in rose and rosewater tourism in relation to the destination offer. To achieve this outcome, the following research questions were developed:

1) What are the features of rose and rose water tourism?

2) What factors affect the choice of rose and rosewater tourism by tourists?

3) What are the destination images and tourist preference factors regarding this kind of tourism? and

4) What are the most influential factors affecting tourist perceptions of preferences and destination image in the study area?

To summarise, this study is important for three reasons. Firstly, it describes the Damask rose, rose water tourism and festivals, as a form of tourism. Secondly, whilst the paper only briefly outlines the literature on tourist destination image and preferences, it then applies it to the 
growing area of research on events and festivals. Additionally, destination image can impact on travel behavior in three time periods; pre-visit, during a visit and post-visit (Tasci \& Gartner, 2007), but Lee and Bai (2016, p.162) note that 'relatively few studies on destination image during a trip have been conducted'. This research contributes to this number. Finally, the study identifies the relative importance of the event offer in relation to the tourism product.

\section{LITERATURE REVIEW}

\section{The Damask Rose and Rose Water}

There are more than 5,000 varieties of roses (Haghighi, Tehranifar, Nikbakht, \& Kafi, 2008), yet only a few of them exhibit the marked fragrance that is sought by perfumeries. The

Damask rose ${ }^{1}$, (Mohammadi Rose in Persian) is the national flower of Iran (Kafi \& Riazi, 2002). Most botanists suggest that it was indigenous there, before being taken to other countries (Mirrazavi, 2015). In the early twelfth century B.C.E., the Damask rose was considered a symbol of love by the Persians (Herbs2000, 2015). It blooms once a year, with each flower having an average of 32 or 33 petals (Nikbakht \& Kafi, 2008). The flowers bloom between late April and June, depending on the weather and most local cultivars are light pink in color.

The processing of the rose also has a long history in the Middle East, with production of rosewater in Persia dating back over 2,500 years (Mirrazavi, 2015). The production of rosewater (known as Golab in Persian) through steam distillation for medical purposes was probably first used by Avicinna, the famous Persian physician, in the 10th century. There is also evidence that commercial distilleries existed in 1612 in Shiraz, Fars Province (Haghighi et al., 2008). Due to its extraordinary fragrance and diversity, the flower is now found in many parts of the world. However, very few countries enjoy ideal conditions for the production of both the Damask rose

\footnotetext{
${ }^{1}$ Rosa damascene, Rosaceus, Rosaceaor, York \& Lancaster Rose, Bulgarian Rose, Damask Rose, Moroccan Rose, Tag-tsi, Tag-tse meto, monthly rose and Persian rose.
} 
itself and the variety required for essential oils and other aromatic substances. At present, besides Iran, the major cultivation areas of Damask roses are in Bulgaria (Kazanlak Valley), Turkey (Isparta, Burdur, Afyon and Denizli), Morocco (El KelaaM'Gouna), Oman (Jebal Akhdar), India (Pushkar/Rajasthan) and Lebanon (Kasarnaba). Bulgaria and Turkey are recognised as the main producers of rose oil while the major producer of fragrant oil and extracts is Greece (Zargari, 1982). Iran is biggest producer of rosewater in world.

An average of $3,000 \mathrm{~kg}$ of rose flowers produce just one $\mathrm{kg}$ of rose oî which is sometimes called liquid gold because of its great value (Dragomirova, 2010). One kilogram of Damask rose, is used to produce every liter of rosewater. Rosewater (created through the steam distillation of rose petals) is widely enjoyed globally for its sweet and deep aroma and delightful and unusual taste. Uses of the fresh or dried roses, rosewater and rose oil are varied and numerous. It has been a popular ingredient for centuries in perfumes, soaps and cosmetics as well as in chocolates, sweets, preserves and liqueurrs. It is used in cooking in Iran and other Arab countries, Turkey, India, and China and especially in pastries, drinks and sweets. In addition to culinary uses, rosewater features in ceremonies of the Muslim, Zoroastrian and Hindu religions. Most famously, the fragrant liquid is used to wash the Holy Kaaba of Mecca, a rite observed twice each year. The plant has also been employed throughout history in traditional medicine to treat various diseases and is still administered today for stress, nervous tension, peptic ulcers and heart disease. It is believed to possess anti-viral, antiseptic, and disinfectant properties (Awale, Tohda, Tezuka, Miyazaki, \& Kadota, 2011; Boskabady, Shafei, Saberi, \& Amini, 2011; Fatemeh, Karimi, Abbassion, Khiabani Rad, \& Karimi Yazdi, 2015; Islamic Republic News Agency, 2015; Nikbakht \& Kafi, 2008). 
The Damask rose is cultivated in several provinces of Iran, covering more than 10,000 hectares and approximately five hundred tons of roses are produced, distilled, and turned into rosewater and rose oil annually. The major Damask rose-related products of Iran are rosewater, rose oil and rose buds (Haghighi et al., 2008). Rosewater is the leftover liquid or hydrosol remaining when the rose petals and water are distilled together when making rose oil. The major Iranian production areas of rose and rosewater are in Kashan, Fars (Maymand), Kerman, and East and West Azerbaijan provinces (Kiai, 2005). The focus in this study is on the Kashan area due to the high quality of its rosewater which can be attributed to natural and climatic conditions and its popularity as a tourist attraction.

Kashan is one of the main cities of Isfahan province, located at an altitude of 1,600 m. above sea level along the edge of the Great Desert. It is $240 \mathrm{~km}$ to the south of Tehran and 220 $\mathrm{km}$ to the north of Isfahan. The town's population is around 400,000, living in an area of 2,100 hectares. The annual Damask Rose Tourism and Festival in the city of Kashan and surrounding districts is famous in Iran and beyond (Chwalkowski, 2016; Iran Daily, 2015).

The area has a thousand hectares of land under Damask rose cultivation with more than 700 tons of annual production. Over 2,000 families are involved in the growing and picking roses and the production of rosewater. The surrounding rural districts such as Ghamsar, Ghahrood, JoshaghanQali, Niyasr, Barzok, Sadeh, Van, Sar, and Vadeqan are the main sources of damask rose and rosewater in the country. But Qamsar is considered to be the most productive region due to the variety, number and availability of Damask roses. The flower picking and extraction of rosewater attracts a considerable number of tourists every year (Mirrazavi, 2015). In common with other Iranian destinations, the majority of visitors to Kashan are domestic tourists, who visit seasonally (Zamani-Farahani \& Musa, 2012), in May and June as rose and 
rosewater tourists. In addition to the seasonal rose and rosewater events, the cultural and religious ceremonies and historical buildings of the region attract many tourists in other months of the year (University of Kashan, 2011).

\section{Rose and Rosewater Festivals and Tourism}

Dimmock and Tiyce (2001) proposed three types of festivals and events: mega events, hallmark events and community-based events; the latter held to celebrate the unique features of communities. According to Ritchie (1984), hallmark events developed to enhance the awareness, appeal and profitability of a destination. Rose and rosewater festivals, as a special event representing a community's unique offerings, could be classified under both hallmark and community-based events. This festival takes place in only a few destinations around the world such as Iran, Bulgaria, Morocco and Saudi Arabia (see Table 1). Festival programmes and special tours vary according to the country and local culture. Rose and Rosewater Tourism takes place only during the Spring rose harvesting period and hence is highly seasonal, starting in late April and continuing to June (depending on region and weather conditions) when the rose farms are most striking visually and the smell of damask rose is striking. At this time, tourists have the opportunity to watch and take part in the rose picking activities while they enjoy rural life. The local family, including children and the elderly, gather in their rose fields every day to pick the flowers before the sunrise with the first dew still on the petals to ensure that no fragrance is lost. The roses are carefully and swiftly picked before the sun's heat evaporates the precious liquid and collected in bags made of large pieces of cloth tied around the picker's neck or in willowbaskets. The picked flowers are then taken to workshops to be distilled into rosewater the same day, often using methods which have remained unchanged for centuries (Iran Daily, 2015). 
Special programmes are organised for tourists during the rose festival period.

Programmes usually include the harvesting of roses, processing of rose water and workshops and seminars. Usually there are also handicraft and food exhibitions, colorful vendors/markets/souks, music and dance performances, the election of a Rose Queen and so forth (Brill Travel, 2018; Iran Daily, 2015; Islamic Republic News Agency, 2015; Travel Exploration, 2015; Egal, 2016).

Hence tourists can see a full demonstration of the traditional and modern rose picking, rosewater and rose oil distillation and production processes. Visitors can also participate in sightseeing programmes which include historical, architectural and cultural sites often within museums. There is also consumption of local food made from or garnished with roses and rosewater and attending local cultural performances and other activities. Tourists can additionally visit rosewater workshops or local cosmetics factories making products from natural rosewater and the local souks, to purchase fresh rose-derived goods directly (Brill Travel, 2018; Chwalkowski, 2016; Islamic Republic News Agency, 2015; Iran Daily, 2015; Keyashiyan, 2014; Qamsar, 2015; Travel Exploration, 2015).

\section{Tourist Attitudes Toward Destination Image}

It is not necessarily the main factor underlying the choice, but the image of a destination may influence tourist behavior (Di Marino, 2010). Destination image is commonly accepted as an important element of successful tourism development and destination marketing due to its impact on both the supply and demand side aspects of marketing (Tasci \& Gartner, 2007). It is difficult to determine tourist's perceptions of destination image as the term has been defined and used differently in a variety of contexts and disciplines. Nevertheless, there tends to be agreement that image represents the destination in the traveler's mind and gives them a pre-taste 
of the destination (Leisen, 2001). The results of a study by Gartner and Ruzzier (2011) implied that the dimensions of image and quality play the most important role in tourists' evaluation of a destination, regardless of whether they are first-time or repeat visitors.

Baloglu and Brinberg (1997) stated that the image construct consists of two components, cognitive and affective. The cognitive, also referred to as the perceptual, is concerned with beliefs and knowledge about an object or destination while the affective is related to feelings or emotions about an object. Consequently, destination image can be defined as the sum of beliefs, ideas and impressions that a person has of a destination (Crompton, 1979). Kim and Richardson (2003) collected all the ideas and summarised the destination image as a totality of impressions, beliefs, ideas, expectations and feelings about a place accumulated over time. Hence, the image of a destination could be shaped through uniqueness, sights, scenes, environmental quality, safety, service levels and the friendliness of the host community.

The ability of tourism destinations to attract tourists depends largely on the position of these destinations in the minds of potential tourists. The projection of a suitable image has been described as a vital factor in attracting tourists (Williams, 2001). Many image producers try to influence the emotional judgment of potential tourists and positively or negatively manipulate their choice through projection of carefully designed images. Ahmed (1996) stated that tourists perceive many images of their destination and the images influence their attitudes and behavior. This suggests that an overall measure of destination image limits marketers' ability to devise positioning strategies and that ideally both positive and negative images of destination attributes should be investigated (White, 2004). A unique character or image is crucial in attracting visitors to a destination and this can be created through special events and festivals. 
Far fewer empirical studies have been undertaken to establish the contribution of a festival or event to a destination image. Moon, Kim, Ko, Connaughton, \& Lee (2011) found that particularly the intangible factors, had a positive influence on the image of destination. Boo and Busser (2006) observed that only a relatively small number of studies have studied local community events, such as the rose water festivals. They cite several studies that demonstrate image improvement associated with hosting festivals and events. Despite this, Yuan and Jang (2008) state that festival quality does not directly affect behavioral intentions while satisfaction and awareness have positive and direct relationships with intentions.

\section{Tourist Preferences}

The demand for recreational travel has increased in much of the world in recent decades (Shieh, Hu, \& Gao, 2014). According to Tran and Ralston (2006), tourist preference is the act of selecting from among a set of choices as influenced by one's motivations. There are numerous studies on the preferences of tourists, Lew (1987) described it as a cross-perspective measure which can be applied to typologies based on one of three perspectives, namely ideographic listing, organisation and tourist cognition of attractions. Based on subsequent studies, it seems that numerous factors can affect the preferences of tourists for destination and the choices made. These include different destination choice patterns for separate segments (Sarma, 2004) and ratings of information sources (internal and external information) for tourism destination products or services affecting the tourists' information search and purchase decision. The tourist characteristics will also influence this rating (Aryanto, 2010). More recently, Mak, Lumbers, Eves, and Chang (2012) identified five major factors (cultural / religious influences, sociodemographic factors, food-related personality traits, exposure effect/past experience and motivational factors) as influencing tourist food consumption. The authors posited that factors 
affecting food consumption in the context of tourism can be classified into three key areas concerning the tourist, the food at the destination and the destination environment.

In terms of events and festivals, the position is similar to that of destination image, with far fewer studies being undertaken and most of those relating to major and mega-events. Again the same as the literature on destination image, community festivals have rarely been the subject of research. However, Kruger, Botha, and Saayman (2012) is an exception, as they studied the associated expenditure in relation to the information source preferences of first-time and repeat visitors at the Wacky Wine Festival in South Africa. However, to date no study appears to consider the preferences of visitors to a festival or event, in relation to the tourism offer.

\section{METHOD}

A survey was conducted of domestic tourists on Damask rose and rosewater tours in the Kashan region during the rose and rose water festivals. The survey sample was a convenience sample (Fox et al., 2014) of Persian-speaking visitors of at least 18 years of age staying at least one or more days and who had purchased a rose and rosewater package tour. A list of travel agencies based in Tehran which organise rose and rosewater daily or weekly package tours and facilitate public visits to Kashan region was used. This list was completed by reference to the Iran Travel Agents Association and review of travel agent's advertisements in popular newspapers. The travel agencies were called by Research Assistants to verify their programmes and enquire about possible cooperation in the project. After consultation, a number agreed to assist.

A questionnaire was developed to examine the characteristics and attitudes of the visitors whilst attending rose and rose water festivals. The research instrument was in the Persian language (Farsi) and designed according to the objectives of the study. Content was drawn from 
previously validated conceptual research into tourists' attitudes, preferences and destination image (Bosque \& Martin, 2008; Castro, Armario, \& Ruiz, 2007; Chi \& Qu, 2008; Cottrell. Duim, Ankersmid, \& Kelder, 2004; Gross \& Brown, 2008; Heung \& Qu, 2000; Mmopelwa. Kgathi, \& Molefhe, 2007; Mohsin, 2005; Molera \& Albaladejo, 2007).

However, the number of statements and the measurement scales were refined and modified to suit the context of this study based on the researchers' personal experiences. A 5point Likert-type scale (strongly disagree $=1$; to strongly agree $=5$ ) was utilised in order to measure the constructs. There were several sections in the questionnaire. Tourist preference was conceptualised as a multidimensional construct of communication, socio-cultural and travel service preferences. Subsequently, the measurement of destination image was derived from items representing the variables such as environmental, economical, socio-cultural and travel services. In the socio-demographic section, the questions were dichotomous and multiple choice. Prior to data collection, a pilot test was undertaken and the comments and suggestions were used to further refine the questionnaire before the collection of the data.

The questionnaires were given to tour managers or directly to tour guides with basic explanations. The intention was that the guides would distribute and collect the questionnaire in the coach at the end of the rose flower picking and extraction tour and rose\& rose water festival. Later, the completed questionnaires were to be collected from travel agencies. However, due to socio-cultural factors a considerable number of questionnaires were only partially completed or appeared to have been completed by tour guides or travel agency staff. These were verified and excluded from the data analysis and a total of 182 questionnaires (out of around 500 questionnaires distributed) were finally analysed. The willingness of respondents to cooperate is related to many factors such as the type of destination, local culture, type of tourist, the 
recognition of the importance and value of the research work by respondents, social codes and even security agents, etc. For these reasons undertaking a field survey is a hard task in Iran. The statistical package for social sciences (SPSS) was employed for the purpose of data management and statistical analysis. Cronbach's coefficient alpha was used to assess the internal consistency of the data and with values of 0.911 for destination image and .712 for tourist preference were deemed 'acceptable' (Kent, 2015). Respondent socio-demographics were profiled in frequencies and percentages. The elements of tourist preferences and destination image were assessed by computing means. Standard multiple regressions were then used to test the predictive power of the set of variables and to evaluate the relative contribution of each individual variable.

\section{RESULTS}

Analysis of the respondent characteristics shows that there were slightly more female respondents $(55.5 \%)$, than males. With regard to age, the results show that $60.2 \%$ were between 18 and 37 years; so that the majority of respondents were therefore young travelers. A total of $52.7 \%$ of the respondents were married and $40.0 \%$ were single, with the remainder engaged to be married or widowed. Concerning educational background, $71.1 \%$ of the respondents had a college/university education which implies that most were well educated. More than half of the respondents opted not to answer the question relating to their religion but the remainder identified themselves as Muslim. Most respondents also chose not to answer the question about their monthly income and occupation and many may have provided inaccurate answers. It appears questions related to religion, income and employment are considered to be private and confidential by Iranian respondents and therefore no data is provided here.

The descriptive statistics for destination image are presented in Table 2. The results show, overall, the respondents had positive perceptions towards rose and rose water tourism. 
Regarding environmental value, the survey revealed that the respondents agreed that the area has beautiful scenery and natural attractions (76.2\%) gorgeous rose gardens $(72.5 \%)$ and is suitable for visiting only during Spring (63.2\%). They also agreed that the weather is pleasant and the place is good for relaxation and rest. On the subject of the cleanliness and tidiness of the environment, only $43.0 \%$ had positive views and $30.1 \%$ expressed neutral opinions. Referring to economic value, respondents perceived that the trip gave them the opportunity to buy a variety of local products (e.g. rosewater and fresh Damask roses) directly from producers at an affordable price $(66.2 \%)$. They believed also that package tours are reasonably priced $(63.0 \%)$ and attractions charge suitable entrance fees $(56.7 \%)$. However, only $44.4 \%$ of respondents agreed that food prices are reasonable and $43.9 \%$ that the area offers value for money. The respondents were agreed that the visited area is a well-known destination, traditional (79.3\%) and popular $(74.1 \%)$ with a variety of historic sites $(71.5 \%)$ and cultural attractions $(61.3 \%)$. There was also agreement that it is a safe place (65.1\%) and that local people are friendly and helpful (63.5\%). Finally, the trip also gave them the chance to have new experiences $(70.4 \%)$.

\section{$<<$ INSERT TABLE 2 HERE $>>>$}

However, in respect of special events/festivals in the region, some respondents held slightly unfavorable attitudes. Only $37 \%$ agreed that there is a variety of special events /festivals and the fact that $80 \%$ felt that more attention needs to be given to this aspect by local authorities is perhaps of concern to providers of tourism services. Nevertheless, just over $70 \%$ considered there to be an abundance of visiting tours and easy accessibility by vehicles and $52.4 \%$ agreed that there is proper regional information and advertising material. On the other hand, only a small proportion of the sample believed that the area has good infrastructure and tourist facilities 
$(41.3 \%)$ and is offering a variety of gastronomic choices $(35.5 \%)$. Finally, about one third believed lodging facilities to be clean and of acceptable quality (see Table 2).

The descriptive statistics for tourist preference are presented in Table 3. Concerning the communication and familiarity factor, the study indicates that travel to new places not previously visited (87.3\%), having information about the area visited (79.4\%) and ability to communicate with local people $(70.9 \%)$ affect tourists attitudes in the areas visited. About two thirds of the visitors tend to take short trips of about 3 days and prefer to travel with family or friends. Travel over a short distance received only $45 \%$ positive views, $27 \%$ neutral, and $30 \%$ negative. While $35.4 \%$ of the tourists stated a preference for traveling to familiar destinations, $36 \%$ stated a negative opinion, and $28.6 \%$ were neutral.

\section{$<<$ INSERT TABLE 3 HERE $>>>$}

Regarding socio-cultural factors, choosing public holiday options for travel (69.3\%), having fun as part of the travel experience $(67.7 \%)$ and appropriate travel costs $(66.2 \%)$ were the most preferred options. Almost 60\% desired a simple and inexpensive trip rather than deluxe travel. Only $44.5 \%$ of respondents showed a preference for domestic travel than international, with about $27 \%$ having a negative opinion and $30.7 \%$ being neutral. There was also a preference for visiting smaller areas rather than large urban centers with $44.5 \%$ supporting this statement, $34.4 \%$ neutral and $21.2 \%$ replying negatively. Regarding the travel facilities factor, tasting and eating new foods was rated the highest item by respondents $(70.4 \%)$ followed by availability of tourist facilities and services at $68.2 \%$. The respondents had positive opinions $(58.2 \%)$ about travel by package tour rather than personal travel. Travel by private vehicle received $40.7 \%$ negative views and $29.1 \%$ of respondents had no comments (see Table 3 ). 
To identify the most important factor influencing the tourist destination image and tourist preferences, standard multiple regressions were used to test the predictive power of the sets of variables and to assess the relative contribution of each individual variable. The beta value was used to compare the contribution of each independent variable, meaning that the variable with the largest beta value makes the strongest contribution in explaining the dependent variable. As presented in Tables 4 and 5, in the case of tourist destination image, all the variables were significant. However, the beta value for tourism services and facilities was greater (0.372), indicating that it made more of a contribution to destination image. Regarding tourism preference in rose and rose water tourism case, the travel facilities were significant among other factors. The statistical results indicate that tourism service and facilities was the most important factor in influencing the perceived tourism image and preference in this study.

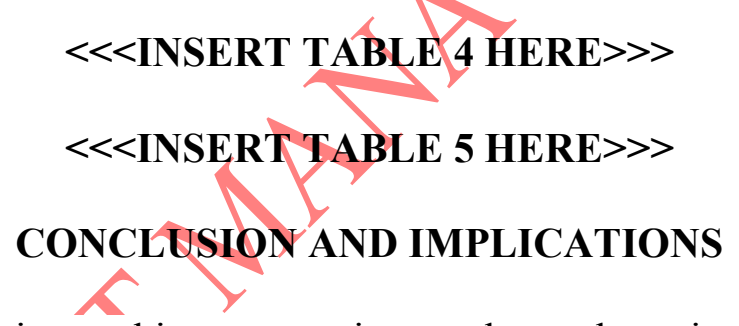

The consumer decision-making process is complex and previous studies have demonstrated that it is difficult to identify this trend. The present research reports on findings from exploratory research which investigates a previously unexplored form of event tourism and seeks to capture the underlying reasons for the attendees' decisions to visit a destination such as the Kashan region of Iran. There are no comprehensive studies available which address these aspects of tourism in the context of a country as a producer of Damask roses. The results of the research revealed that the majority of respondents were female, young, married, well-educated and travelling either individually or with family members. The survey found that tourists regarded the beauty of the rose gardens, popularity of area, variety of historic sites, abundance of 
tours; originality of the place and friendless and helpfulness of local people as positive features. However, they were not particularly impressed with the cleanness and tidiness of the environment, reasonableness of food prices, proper regional information and advertising material, variety of cultural events/festivals, diversity of gastronomic offerings, local infrastructure and tourist facilities and quality and cleanliness of lodging facilities. The respondents stated that more attention should be paid to the area by local authorities. These factors may explain why the number of outbound tourists exceeds inbound tourism in Iran (Asadi \& Daryaei, 2011; Manghutay, 2015). The findings also show that novelty of place/event, availability of information, access to appropriate travel services, interaction with the locals, eating local produce, cost of trip, travel packages, travelling with families and possibility of staying longer in a place were significant factors in the destination selection process. However, the distance, familiarity of a place and travelling by private transport were not such important factors in the decision to visit this area. The results also suggest that rose and rosewater tourism as a special interest tourism activity provides opportunities for those interested in leisure, fun, nature, rural life and getting away from daily routine.

Rose and rosewater tourism could be more beneficial than other types of cultural and recreational tourism as a source of educational experiences and economic development in rural areas. As Jafari and Scott (2014) note, it could also be used in combination with traditional pilgrimage and religious experiences. Better planning and marketing is necessary and the region's authorities should formulate communication and product development strategies to increase the success of this form of tourism at domestic and international levels. Initially, emphasis should be on the former as the majority of tourists are local. 
The results show that the tourism facilities and services are the most important factors influencing the visitors' attitudes. Satisfaction with facilities and services plays a significant role in determining overall satisfaction with travel/tourism experiences which, in turn, plays an important role in satisfaction in the leisure domain (Neal, Uysal, \& Sirgy, 2007). Having a clear understanding of travelers' image and attitudes is thus vital for developing successful marketing strategies to promote and position a destination and the festivals and events it supports.

Destination marketing strategies generally are responsible for developing a unique image of the area, coordinating private and public tourism industry sectors, providing information facilities for visitors, and leading the overall tourism industry at a destination (Prideaux \& Cooper, 2002). Whilst the growing of the crop and the processing and consumption may be the focal points of the festival offer, if there is the additional ambition to grow event attendance and tourism, the planning and management of the tourism element is equally essential, if both destination development and festival are to be successful and viable in the long-term. The tourism management and marketing bodies should be aware of all elements that will improve their product and image of the destination (Dominique \& Lopes, 2011) as well as try to provide further recreational activities; improved infrastructure and facilities to be offered to tourists during the tourism season. Furthermore, in order to have a successful tourism destination, lessons should be learnt from past mistakes. Strategic management and proper marketing planning can lead to the optimisation of tourism impacts and the achievement of objectives for all stakeholders (Buhalis, 2000). Destinations should look at domestic, regional, and international stakeholders including government, official bodies and private enterprises. Marketing of a destination is a complex task involving the coordination of a range of public and private concerns as well as the host community in projecting an appealing image and commensurate tourism offering for the 
would-be visitor. This is a challenging task given the lack of control over the components which make up the possible offering, but it would seem that there is untapped potential in the case of rose-themed travel in parts of Iran. It requires a desire and willingness from the local authorities to enhance the tourism offer as indicated above, to attract more international visitors, particularly from the West, given the possibilities generated by the lifting of economic sanctions.

It is important to mention the limitations of the study, some of which are due to general socio-cultural obstacles. There were problems securing the cooperation of the local tourism industry (i.e. travel agency managers and employees and tour guides) which is common to much research conducted in Iran. Also there was unwillingness by respondents to disclose confidential information such as their religion and occupation. The authors suggest a more complete understanding of rose and rose water tourism can inform and enhance destination marketing. To develop a more accurate and comprehensive picture of this kind of special interest event tourism, further research and evaluation should be considered in the same and similar destinations with rose and rosewater tourism possibilities. This research could include specific questions relating to the Festivals - including for example, the number of attendances, motivation for visiting and means of travel. Nevertheless, the present study contributes new knowledge in an event tourism field that is under-researched. 


\section{REFERENCES}

Ahmed, Z. U. (1996). The need for the identification of the constituents of a destination's tourist image: A promotional segmentation perspective. Tourism Review, 51(2), 44-57.

Aryanto, R. (2010). Tourist preference for tourism destinations information sources (tourist's preference on ratings information sources affected by tourists' shared characteristic to Jakarta's tourism destinations). In 2nd International Conference on Management, Hospitality \& Tourism, and Accounting, Jakarta, 12 - 13 November.

Asadi, R., \& Daryaei, M. (2011). Analysis and prioritization of push factors of Iranian outbound tourists. Australian Journal of Basic and Applied Sciences, 5(11),780-787.

Awale, S., Tohda, C., Tezuka, Y., Miyazaki, M., \& Kadota, S. (2011) Protective effects of Rosa damascene and its active constituent on A $\beta(25-35)$-Induced Neuritic Atrophy. Evidencebased complementary and alternative medicine. Article ID 131042, 8, http://dx.doi.org/10.1093/ecam/nep149 ; Retrieved April 9, 2015, from www.ncbi.nlm.nih.gov/pmc/articles/PMC3162985/

Backman, K. F., Backman, S.J., Uysal, M., \& Sunshine, K. M. (1995). Event tourism: An examination of motivations and activities. Festival Management and Event Tourism, $3(1), 15-24$.

Baloglu, S., \& Brinberg, D. (1997). Active images of tourism destinations. Journal of Travel Research, 35(4), 11-15.

Boo, S. Y., \& Busser, J. A. (2006). Impact analysis of a tourism festival on tourists destination images and satisfaction. Event Management, 9(4), 165-181.

Boskabady, I. H., Shafei, M. N., Saberi, Z., \& Amini, S. (2011). Pharmacological effects of Rosa Damascena. Iranian Journal of Basic Medical Sciences, 14(4), 295-307. 
Bosque, I. R. D., \& Martin, H. S. (2008). Tourism satisfaction: A cognitive-affective model. Annals of Tourism Research, 35(2), 551-573.

Brill Travel. (2018). 2018 Rose Festival in Bulgaria. Retrieved May 7, 2018, from http://brilltravel.com/tours/2018-rose-festival-bulgaria/

Buhalis, D. (2000). Marketing the competitive destination of the future. Tourism Management, 21(1), 97-116.

Candrea, A. N., \& Ispas, A. (2010). Promoting tourist destinations through sport events: The case of Braşov. Revista De Turism - Studii Si Cercetari in Turism, 10(10), 61-67.

Castro, B. C., Armario, E. M., \& Ruiz, D. M. (2007). The influence of market heterogeneity on the relationship between a destination's image and tourists future behavior. Tourism Management, 28(1), 175-187.

Chi, C. G. Q., \& Qu, H. (2008). Examining the structural relationships of destination image, tourist satisfaction and destination loyalty: An integrated approach. Journal of Tourism Management, 29(4), 624-636

Chwalkowski, F. (2016). Symbols in arts, religion and culture: The soul of nature (Chapter 3). UK: Cambridge Scholars Publishing.

Cottrell, S. P., Duim, R., Ankersmid, P., \& Kelder, L. (2004). Measuring the sustainability of tourism in Manuel Antonio and Texel: A tourist perspective. Journal of Sustainable Tourism, 12(5), 409-432.

Crompton, J. L. (1979). Motivations for pleasure vacation. Annals of Tourism Research, 6(4), $408-424$. 
Devine, A. \& Devine, F. (2017). A Strategic Approach to International Event Tourism. In: N. Ferdinand \& P. J. Kitchin (Eds.), Events management: An International approach (pp. 317-333). London: Sage Publications Ltd.

Di Marino, E. (2010). The strategic dimension of destination image. An analysis of the French Riviera Image from the Italian tourists' perceptions. PhD Thesis, University of Naples "Federico II", Italy.

Dimmock, K., \& Tiyce, M. (2001). Festivals and events: Celebrating special interest tourism. In: N. Douglas, N. Douglas, \& R. Derrett (Eds.), Special interest tourism: Context and cases. (pp. 355-383). Brisbane: John Wiley \& Sons.

Dominique, S., \& Lopes, F. (2011). Destination image: Origins, developments and implications. PASOS, 9(2), 305-315.

Dragomirova, D. (2010). Bulgarian rose oil and the festival of roses. Retrieved April.9, 2015, from www.topics-mag.com/edition26/bulgaria/bulgarian_rose_oil_festival.html

Dwyer, L., Forsyth, P., \& Spurr, R. (2005). Estimating the impacts of special events on an economy. Journal of Travel Research, 43(4), 351-359.

Egal, F. (2016). Celebrating the, iconic jewel of the Garden of Hejaz, The rose of Taif. Retrieved 30.03. 2017, from http://www.saudiarabiatourismguide.com/taif-rose-festival/

Fatemeh, F., Karimi, A., Abbassion, M., Khiabani Rad, P., \& Karimi Yazdi, M. (2015). Extraction of Rosa damascena as an antibacterial agent. International Journal of Mycobacteriology, 4(1), 169. https://doi.org/10.1016/j.ijmyco.2014.11.053

Fox, D., Gouthro, M., Morakabati, Y., \& Brackstone, J. (2014). Doing events research: From theory to practice. Abingdon: Routledge. 
Gartner, W. C., \& Ruzzier, M. K. (2011). Tourism destination brand equity dimensions. Journal of Travel Research, 50(5), 471-481.

Getz, D. (2013). Event tourism: Concepts, International case studies and research. New York: Cognizant Communication Corporation.

Ghaderi, Z. (2011). Domestic Tourism in Iran. Anatolia - An International Journal of Tourism and Hospitality Research, 22(2), 278-281.

Gross. M. J., \& Brown, G. (2008). An empirical structural model of tourists and places: Progressing involvement and place attachment into tourism. Tourism Management, 29(6), $1141-1151$.

Haghighi, M., Tehranifar, A., Nikbakht, A., \& Kafi, M. (2008). Research and current profile of Iranian production of Damask Rose (Rosa damascene Mill.). ActaHorticulturea, 769, $449-45$.

Herbs2000. (2015). History of the Rose. Retrieved September 15, 2015, from www.herbs2000.com/flowers/phistory.htm

Heung, V. C. S., \& Qu, H. (2000). Hong Kong as a travel destination: An analysis of Japanese tourists' satisfaction levels and the likelihood of them recommending Hong Kong to others. Journal of Travel \& Tourism Marketing, 9(1/2), 57-80.

Iran Daily. (2015) Røsewater festival in Kashan. Retrieved September 13, 2015, from www.irandaily.com/News/117630.html.

Islamic Republic News Agency (2015). Festival of Rose and Rose. Retrieved September 16, 2015, from water.www.irna.ir/en/News/81599845/. 
Jafari, J., \& Scott, N. (2014). Muslim world and its tourism. Annals of Tourism Research, 44(1), $1-19$.

Kafi, M., \& Riazi, Y. (2002). Cultivation of rosadamascena mill and rose water production. Ministry of Agricultural. Tehran: Jahad Publication (In Persian).

Kent, R. (2015). Analysing quantitative data. London: Sage Publications Ltd.

Keyashiyan. (2014). Apps season of rose and rose water festival in Kashan. Retrieved October 23, 2014, from http://www.keyashiyan.com/modules.php?name=News\&file=article $\&$ sid $=4564$

Khodadadi, M. (2016). A new dawn? The Iran nuclear deal and the future of the Iranian tourism industry. Tourism Management Perspectives. 18, 6-9 (In Persian)

Kiai, S. (2005). Director General of ornamental flower and plants. Ministry of AgriculturalJihad. ISNA News, 22 March 2005 (In Persian).

Kim, H., \& Richardson, S. (2003). Motion picture impacts on destination images. Annals of Tourism Research, 30(1), 216237.

Kruger, M., Botha, K., \& Saayman, M. (2012). Information source preferences and associated expenditure of first-time and repeat visitors at a South African wine festival. Tourism Analysis, 17(3), 343-355.

Lee, S., \& Bai, B. (2016). Influence of popular culture on special interest tourists' destination image. Tourism Management, 52,161-169.

Leisen, B. (2001). Image segmentation: The case of a tourism destination. Journal of Services Marketing, 15 (1), 49-66.

Lew, A. A. (1987). A framework of tourist attraction research. Annals of Tourism Research, 14(4), 553-575. 
Mak, A. H. N., Lumbers, M., Eves, A., \& Chang, R. C. Y. (2012). Factors influencing tourist food consumption. International Journal of Hospitality Management, 31(3), 928-936.

Manghutay, A. G. (2015). Iran's inbound tourism related policies: Foreigners are not welcome. Journal of Tourism, Hospitality and Sports, 6, 14-27.

Mirrazavi, F. (2015). Festival of Rose and Rose Water. Retrieved October 3, 2015, from http://www.iranreview.org/content/Documents/Festival_of_Rose_and_Rose_Water.htm

Mmopelwa, G., Kgathi, D. L., \& Molefhe, L. (2007). Tourists' perceptions and their willingness to pay for park fees: A case study of self-drive tourists and clients for mobile tour operators in Moremi Game Reserve, Botswana. Tourism Management, 28(4), 1044-1056.

Mohsin, A. (2005). Tourist attitudes and destination marketing the case of Australia's Northern Territory and Malaysia. Tourism Management, 26(5), 723-732.

Molera, L., \& Albaladejo, I.P. (2007). Profiling segments of tourists in rural areas of SouthEastern Spain. Tourism Management, 28(3), 757-767.

Morakabati, Y. (2011). Deterrents to tourism development in Iran. International Journal of Tourism Research, 13(2), 103-123.

Moon, K. S., Kim, M., Ko, Y.L., Connaughton, D. P., \& Lee, J. H. (2011). The influence of consumer's event quality perception on destination image. Managing Service Quality, 21(3), 287-303.

Neal, J. D., Uysal, M., \& Sirgy, M. J. (2007). The effect of tourism services on travelers' quality of life. Journal of Travel Research, 46(2), 154-163.

Nikbakht, A., \& Kafi, M. (2008) A study on the relationships between Iranian people and Damask Rose (Rosa Damascena) and its therapeutic and healing properties. In E. Matsuo, P. D. Relf, \& M. Burchett (Eds.), VIII International People-Plant Symposium on 
Exploring Therapeutic Powers of Flowers, Greenery and Nature 790. DOI: https://10.17660/ActaHortic.2008.790.36

Prideaux, B., \& Cooper, C. (2002). Marketing and destination growth: A symbiotic relationship or simple coincidence? Journal of Vacation Marketing, 9(1), 5-51.

Qamsar. (2015). Twelfth Festival of rose and rose water was held in Ghamsar. Retrieved April 07, 2015, from http://www.qamsar.ir/ShowNews.aspx?ID=185

Read, S. E. (1980). A prime force in the expansion of tourism in the next decade: Special interest travel. In D. E. Hawkins, E. L. Shafer, \& J. M. Rovelstad, (Eds.), Tourism marketing and management issues (pp. 193-202). Washington DC: George Washington University.

Ritchie, J. R. B. (1984). Assessing the impact of hallmark events: Conceptual and research issues. Journal of Travel Research, 23(1), $2-11$.

Sarma, M. K. (2004). Destination choice pattern and tourist segments. In A. Raj (Ed.), Tourist Behaviour: A Psychological Rerspective (pp. 137-149). New Delhi: Kanishka.

Shieh, H. S., Hu, J. L., \& Gao, L. Y. (2014). Tourist preferences and cost efficiency of international tourist hotels in Taiwan. International Journal of Marketing Studies, 6(3), $35-48$.

Tasci, A. D. A., \& Gartner, W. C. (2007). Destination image and its functional relationships. Journal of Travel Research, 45(4), 413-425.

Tran, X., \& Ralston, L. (2006). Tourist preferences influence of unconscious needs. Annals of Tourism Research, 33(2), 424-441.

Travel Exploration (2015). Kallet Des Mgouna Valley of Roses Tour. Retrieved July 22, 2015, from http://www.travel-exploration.com/subpage.cfm/Rose_Festival> 
United Nations World Tourism Organisation. (2007). A practical guide to tourism destination management. Madrid (Spain): World Tourism Organization (UNWTO) Publishing.

University of Kashan. (2011). City of Kashan. Retrieved October 24, 2014, from https://kashanu.ac.ir/en/page/1687/city-of-kashan

Williams, G. (2001). Will Europe's charter carriers be replaced by "no-frills" scheduled airlines? Journal of Air Transport Management, 7(5), 277-286.

White, C. J. (2004). Destination image: To see or not to see? International $\widehat{\text { ournal of }}$ Contemporary Hospitality Management, 16(5), 309-314.

Yuan, J. \& Jang, S. (2008). The effects of quality and satisfaction on awareness and behavioral intentions: exploring the role of a wine festival. Journal off Travel Research, 46(3), 27988.

Zamani-Farhani, H. (2013). Cultural heritage events and tourism: A case of NowRuz. Tourism Recreation Research, 38(2), 249-254.

Zamani-Farhani, H., \& Musa, G. (2012). The relationship between Islamic religiosity and residents' perceptions of socio-cultural impacts of tourism in Iran: Case studies of Sare'in and Masooleh. Tourism Management, 33(4), 802-814.

Zargari, A. (1982) Therapeutic plants. Vol (1). Tehran: Tehran University Press (In Persian). 
Table1.

Main Annual Damask Rose Festivals

\begin{tabular}{|c|c|c|c|c|}
\hline Festival & Place & Date & Flower & Feature \\
\hline $\begin{array}{l}\text { Rose and Rose } \\
\text { Water Festival } \\
\text { (Gol-o-Golab } \\
\text { Festival) }\end{array}$ & $\begin{array}{l}\text { Iran, Kashan } \\
\text { (Qamsar, } \\
\text { Mashhad } \\
\text { Ardehal, } \\
\text { Niasar \& } \\
\text { Joshaghan) }\end{array}$ & $\begin{array}{l}\text { May } \\
\text { (3-6 days) } \\
\text { Visiting tours } \\
\text { take place for } \\
\text { a period of } 2 \\
\text { months. }\end{array}$ & $\begin{array}{l}\text { Damask } \\
\text { rose }\end{array}$ & $\begin{array}{l}\text { It is combination of horticultural, education, } \\
\text { fun and commerce with religious ritual. It } \\
\text { joins sales with seminars on rose breeding, } \\
\text { people take part in processions, visitors can } \\
\text { see how rosewater is extracted, and rose oil } \\
\text { distilled. Handicrafts and tourism exhibitions, } \\
\text { as well as cultural and artistic programs are } \\
\text { also included. In addition, the ceremony of } \\
\text { dusting off the pilgrimage places and } \\
\text { cleaning of holy shrines are held. }\end{array}$ \\
\hline Rose Festival & $\begin{array}{l}\text { Bulgaria, } \\
\text { Kazanlak }\end{array}$ & $\begin{array}{l}\text { First weekend } \\
\text { in June }\end{array}$ & $\begin{array}{l}\text { Damask } \\
\text { rose }\end{array}$ & $\begin{array}{l}\text { The Festival has been taken place since } 1903 \\
\text { in Kazanlak. It includes early morning } \\
\text { harvesting ritual in the rose fields, the } \\
\text { election of Queen Rose and the parade along } \\
\text { the streets of each town, choir a cappella and } \\
\text { folklore concerts, art shows, exhibitions, } \\
\text { wine-tasting, gourmet show. }\end{array}$ \\
\hline Roses Festival & $\begin{array}{l}\text { Morocco, } \\
\text { El Kalaa } \\
\text { M'Gouna }\end{array}$ & $\begin{array}{l}\text { Mid May } \\
\text { (3 days) }\end{array}$ & & $\begin{array}{l}\text { The Rose Festival is attended by local } \\
\text { villagers and celebrated with traditional } \\
\text { Berber music, food and dance. The Festival } \\
\text { features an exhibition of local crafts and } \\
\text { a street-parade with bright colourful floats } \\
\text { made out of faux roses whereby the Ms. } \\
\text { Roses of El Kelaa Des Mgouna is chosen. }\end{array}$ \\
\hline $\begin{array}{l}\text { Taif Rose } \\
\text { Festival }\end{array}$ & $\begin{array}{l}\text { Saudi Arabia, } \\
\text { King Faisal } \\
\text { Park in }\end{array}$ & $\begin{array}{l}\text { March-April } \\
\text { (lasts more } \\
\text { than a week) }\end{array}$ & $\begin{array}{l}\text { Damask } \\
\text { rose }\end{array}$ & $\begin{array}{l}\text { The Festival has been taken place since } 13 \\
\text { years ago. One of the festival's highlights is a } \\
\text { flower carpet prepared by Taif Municipality } \\
\text { spreading over } 750 \text { square meters. The } \\
\text { festival hosts various pavilions at the festival } \\
\text { set up by different government and private } \\
\text { organizations, displayed along areas for } \\
\text { traditional eatable, handicrafts; folk dances; } \\
\text { selling flowers, rose oil and rose water; and } \\
\text { cultural contests for children. }\end{array}$ \\
\hline
\end{tabular}

Sources: Brill Travel, 2018; Islamic Republic News Agency, 2015; Iran Daily, 2015; Keyashiyan, 2014; Qamsar, 2015; Travel Exploration, 2015; Egal (2016). 
Table 2.

Items Used for the Measurement of Destination Image of Rose and Rose Water Tourism

\begin{tabular}{|c|c|c|c|c|c|c|c|}
\hline Factors & $\mathbf{1}$ & 2 & 3 & 4 & 5 & Mean & SD \\
\hline \multicolumn{8}{|l|}{ A- Environmental values (\%) } \\
\hline $\begin{array}{c}\text { Beautiful scenery and } \\
\text { natural attractions }\end{array}$ & 1.1 & 4.2 & 18.5 & 53.4 & 22.8 & 3.94 & .83 \\
\hline $\begin{array}{l}\text { Gorgeous rose gardens and } \\
\text { springs }\end{array}$ & - & 6.9 & 20.6 & 49.2 & 23.3 & 3.99 & .82 \\
\hline Pleasant weather & 3.2 & 8.5 & 29.1 & 40.2 & 19.0 & 3.56 & 1.06 \\
\hline A place for relaxation $\&$ rest & 4.2 & 9.0 & 28.5 & 41.8 & 16.4 & 3.63 & 1.04 \\
\hline Clean and tidy environment & 6.9 & 20.1 & 30.1 & 30.7 & & 3.19 & 1.06 \\
\hline $\begin{array}{l}\text { Suitable for visiting only } \\
\text { during spring }\end{array}$ & 2.1 & 7.4 & 26.4 & 43.4 & & & .81 \\
\hline \multicolumn{8}{|l|}{ B-Economical values (\%) } \\
\hline Food prices are reasonable & 4.8 & 23.3 & 27.5 & 32.8 & 11.6 & 3.19 & 1.07 \\
\hline Value for money & 2.1 & 19.6 & 34.4 & 33.3 & 10.6 & 3.31 & .93 \\
\hline $\begin{array}{l}\text { Appropriate price of } \\
\text { package tours }\end{array}$ & 1.6 & 10.1 & & 48.7 & 14.3 & 3.70 & .90 \\
\hline $\begin{array}{l}\text { Suitable attractions } \\
\text { entrance fees }\end{array}$ & 1.6 & & & 42.9 & 13.8 & 3.63 & .89 \\
\hline $\begin{array}{l}\text { Buying all kinds of local } \\
\text { products (like rosewater) } \\
\text { directly from producers } \\
\text { with affordable prices }\end{array}$ & 1.6 & & 26.4 & 46.6 & 19.6 & 3.84 & .85 \\
\hline \multicolumn{8}{|l|}{ C-Socio-Cultural values (\%) } \\
\hline Safe \& peaceful place & .5 & 1.6 & 32.5 & 50.3 & 14.8 & 3.83 & .72 \\
\hline $\begin{array}{c}\text { Variety of special } \\
\text { events/festivals }\end{array}$ & 5.8 & 13.8 & 43.4 & 25.9 & 11.1 & 3.26 & .97 \\
\hline $\begin{array}{l}\text { Friendly and helpfullocal } \\
\text { people }\end{array}$ & .5 & 4.2 & 31.7 & 51.3 & 12.2 & 3.74 & .79 \\
\hline $\begin{array}{l}\text { Variety of cultural } \\
\text { attractions }\end{array}$ & 1.1 & 9.0 & 28.5 & 44.4 & 16.9 & 3.63 & .91 \\
\hline $\begin{array}{l}\text { Well-known and famous } \\
\text { destination }\end{array}$ & 1.1 & 2.1 & 13.7 & 55.6 & 27.5 & 4.08 & .78 \\
\hline $\begin{array}{l}\text { A place to gain new } \\
\text { experiences }\end{array}$ & 1.6 & 4.8 & 23.3 & 51.9 & 18.5 & 3.83 & .79 \\
\hline Traditional place & .5 & 2.6 & 17.4 & 53.4 & 25.9 & 3.92 & .79 \\
\hline Full of visitors/tourists & 1.6 & 2.6 & 21.7 & 50.8 & 23.3 & 4.00 & .78 \\
\hline Variety of historic sites & 1.1 & 2.6 & 24.8 & 45.0 & 26.5 & 3.89 & .86 \\
\hline
\end{tabular}




\begin{tabular}{|c|c|c|c|c|c|c|c|}
\hline $\begin{array}{c}\text { Quality and cleanliness of } \\
\text { lodging facilities }\end{array}$ & 9.5 & 23.3 & 33.8 & 22.8 & 10.6 & 3.25 & .97 \\
\hline $\begin{array}{c}\text { Easy accessibility (by } \\
\text { vehicles) }\end{array}$ & .5 & 5.3 & 23.8 & 52.4 & 18.0 & 3.85 & .78 \\
\hline $\begin{array}{c}\text { Good infrastructure \& } \\
\text { tourist facilities }\end{array}$ & 9.0 & 22.8 & 27.0 & 29.1 & 12.2 & 3.37 & 1.08 \\
\hline $\begin{array}{c}\text { Variety of gastronomic } \\
\text { offering }\end{array}$ & 10.6 & 20.6 & 33.3 & 25.4 & 10.1 & 3.16 & 1.11 \\
\hline $\begin{array}{c}\text { More attention needs to be } \\
\text { paid in this areas by local } \\
\text { authorities }\end{array}$ & 3.2 & 1.6 & 15.8 & 34.4 & 45.0 & 4.08 & .90 \\
\hline $\begin{array}{c}\text { Proper regional information } \\
\text { and advertising material }\end{array}$ & 3.2 & 15.9 & 28.5 & 32.8 & 19.6 & 3.46 & 1.01 \\
\hline Abundance of visiting tours & 1.1 & 4.2 & 24.3 & 47.1 & 23.3 & 4.00 & .78 \\
\hline
\end{tabular}


Table 3.

Items Used for the Measurement of Tourist Preference

\begin{tabular}{|c|c|c|c|c|c|c|c|}
\hline Factors & 1 & 2 & 3 & 4 & 5 & Mean & SD \\
\hline \multicolumn{8}{|l|}{ A-Communication \& familiarity $(\%)$} \\
\hline $\begin{array}{l}\text { Preference to go to places that have not } \\
\text { been seen before }\end{array}$ & - & 3.7 & 9.0 & 42.3 & 45.0 & 4.20 & .76 \\
\hline $\begin{array}{l}\text { Collecting information before a trip } \\
\text { will affect decision-making }\end{array}$ & .5 & 1.6 & 18.5 & 56.6 & 22.8 & 4.02 & .69 \\
\hline $\begin{array}{l}\text { Preference to travel to familiar } \\
\text { destinations, rather than to exotic and } \\
\text { strange ones }\end{array}$ & 5.8 & 30.2 & 28.6 & 28.0 & & 3.16 & 1.03 \\
\hline Preference to stay longer in this area & 1.6 & 5.3 & 27.0 & 52.4 & 13.8 & 3.81 & .88 \\
\hline $\begin{array}{l}\text { Preference to interact with the locals in } \\
\text { trip }\end{array}$ & - & 3.7 & 25.4 & & 21.2 & 3.85 & .74 \\
\hline Preference to travel with own family & 2.6 & 4.2 & 27.5 & 37.0 & 28.6 & 3.77 & .92 \\
\hline Preference to travel with friend (s) & 1.1 & 7.4 & 32.8 & 41.3 & 17.5 & 3.53 & .85 \\
\hline $\begin{array}{l}\text { One of the reasons I travel, is to } \\
\text { travel around the area }\end{array}$ & 5.3 & 25.4 & 24,3 & 27.0 & 18.0 & 3.35 & 1.10 \\
\hline $\begin{array}{l}\text { Preference for short-term travel (one to } \\
\text { three days) rather than long-term }\end{array}$ & 3.2 & 6.4 & 21.2 & 42.3 & 16.9 & 3.53 & 1.01 \\
\hline \multicolumn{8}{|l|}{ B-Socio-Cultural (\%) } \\
\hline $\begin{array}{c}\text { Travel experience is more inter } \\
\text { than any other entertainment }\end{array}$ & .5 & 6.9 & 24.9 & 42.3 & 25.4 & 3.75 & .89 \\
\hline $\begin{array}{l}\text { Preference to visit small or isolated } \\
\text { rural area than urban region }\end{array}$ & 3.2 & 18.0 & 34.4 & 32.3 & 12.2 & 3.33 & .94 \\
\hline $\begin{array}{l}\text { Preference to take trip during } \\
\text { public holidays }\end{array}$ & 1.1 & 16.4 & 23.3 & 36.5 & 22.8 & 3.72 & .99 \\
\hline $\begin{array}{l}\text { Preference to have simple trip to } \\
\text { luxurious and expensive travel }\end{array}$ & 2.1 & 8.5 & 31.7 & 44.4 & 13.2 & 3.57 & .84 \\
\hline $\begin{array}{l}\text { Preference to } \\
\text { travel domestically than abroad }\end{array}$ & 12.7 & 14.3 & 28.6 & 30.7 & 13.8 & 3.36 & 1.10 \\
\hline $\begin{array}{l}\text { Preference to visit a place with } \\
\text { reasonable cost }\end{array}$ & 1.6 & 5.3 & 27.0 & 52.4 & 13.8 & 3.73 & .79 \\
\hline \multicolumn{8}{|l|}{ C- Travel Facilities (\%) } \\
\hline $\begin{array}{l}\text { Preference to travel in a package tour } \\
\text { rather than independently }\end{array}$ & 2.1 & 14.8 & 24.9 & 38.1 & 20.1 & 3.62 & .99 \\
\hline Preference to travel by my own car & 9.0 & 31.7 & 29.1 & 22.2 & 7.9 & 3.09 & 1.08 \\
\hline Preference to eat local foods & 1.6 & 4.8 & 23.3 & 48.7 & 21.7 & 3.80 & .90 \\
\hline $\begin{array}{l}\text { Availability of appropriate travel } \\
\text { services is one of the reasons to } \\
\text { choose a region for the trip }\end{array}$ & 1.1 & 9.0 & 21.2 & 49.2 & 19.0 & 4.09 & 3.91 \\
\hline
\end{tabular}


Copyright (C) 2018 Cognizant Communication Corporation

Table 4.

Standard Multiple Regression between Destination Image Variables

\begin{tabular}{|c|c|c|c|c|c|}
\hline & $\begin{array}{r}\text { Unsta } \\
\text { Cot }\end{array}$ & $\begin{array}{l}\text { dardized } \\
\text { icients }\end{array}$ & $\begin{array}{c}\text { Standardized } \\
\text { Coefficients }\end{array}$ & & \\
\hline Variables & $\mathbf{B}$ & Std. Error & Beta & $\mathbf{t}$ & Sig. \\
\hline Environmental value & .891 & .028 & .237 & 31.866 & .000 \\
\hline Economic value & .991 & .037 & .226 & 26.738 & .000 \\
\hline Socio-Cultural value & .979 & .023 & .343 & 43.031 & .000 \\
\hline $\begin{array}{l}\text { Tourism Services \& } \\
\text { Facilities values }\end{array}$ & 1.122 & .022 & .372 & 50.009 & .000 \\
\hline
\end{tabular}


Table 5.

Standard Multiple Regression between Tourist Preference Variable

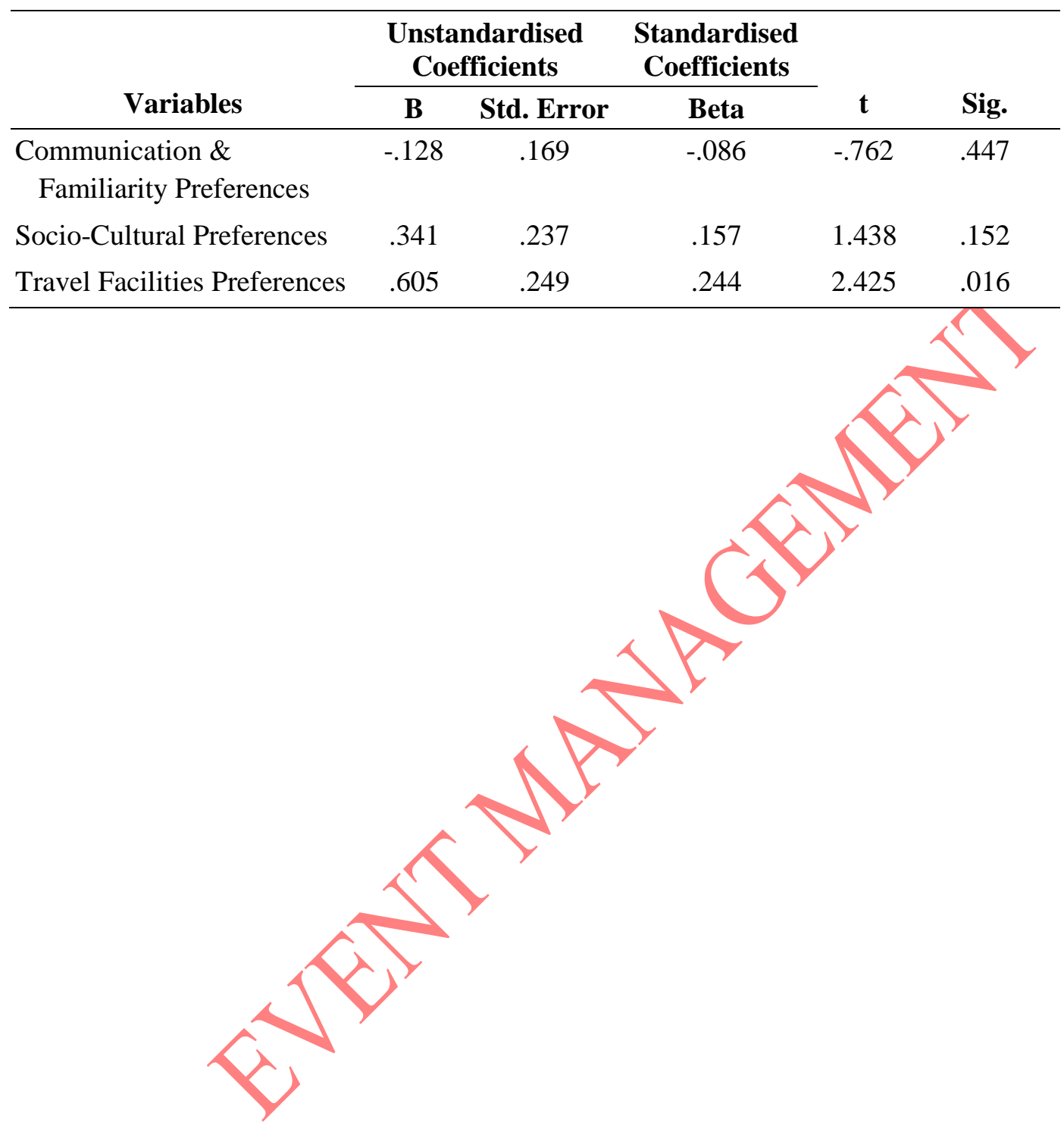

